\title{
Tr1-Like T Cells - An Enigmatic Regulatory T Cell Lineage
}

\author{
Anna Malgorzata White ${ }^{1}$ and David C. Wraith ${ }^{1,2 *}$ \\ ${ }^{1}$ School of Cellular and Molecular Medicine, University of Bristol, Bristol, UK, ${ }^{2}$ Institute of Immunology and Immunotherapy, \\ University of Birmingham, Birmingham, UK
}

OPEN ACCESS

Edited by:

Duncan Howie,

University of Oxford, UK

Reviewed by:

Anne Cooke,

University of Cambridge, UK

Alf Hamann,

German Rheumatism Research

Centre Berlin and Charité -

Universitätsmedizin Berlin, Germany

${ }^{*}$ Correspondence:

David C. Wraith

d.wraith@bham.ac.uk

Specialty section:

This article was submitted to

Immunological Tolerance,

a section of the journal

Frontiers in Immunology

Received: 15 June 2016

Accepted: 31 August 2016

Published: 14 September 2016

Citation:

White AM and Wraith DC (2016)

Tr1-Like T Cells - An Enigmatic

Regulatory T Cell Lineage.

Front. Immunol. 7:355.

doi: 10.3389/fimmu.2016.00355
The immune system evolved to respond to foreign invaders and prevent autoimmunity to self-antigens. Several types of regulatory $T$ cells facilitate the latter process. These include a subset of Foxp3- ${ }^{-}$CD4 ${ }^{+} \mathrm{T}$ cells able to secrete $\mathrm{IL}-10$ in an antigen-specific manner, type 1 regulatory (Tr1) T cells. Although their suppressive function has been confirmed both in vitro and in vivo, their phenotype remains poorly defined. It has been suggested that the surface markers LAG-3 and CD49b are biomarkers for murine and human Tr1 cells. Here, we discuss these findings in the context of our data regarding the expression pattern of inhibitory receptors (IRs) CD49b, TIM-3, PD-1, TIGIT, LAG3 , and ICOS on Tr1-like human T cells generated in vitro from $\mathrm{CD}^{+}$memory $\mathrm{T}$ cells stimulated with $\alpha \mathrm{CD} 3$ and $\alpha \mathrm{CD} 28$ antibodies. We found that there were no differences in

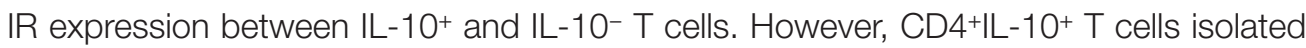
ex vivo, following a short stimulation and cytokine secretion assay, contained significantly higher proportions of $\mathrm{TIM}-3^{+}$and PD-1+ cells. They also expressed significantly higher TIGIT mRNA and showed a trend toward increased TIM-3 mRNA levels. These data led us to conclude that large pools of IRs may be stored intracellularly; hence, they may not represent ideal candidates as cell surface biomarkers for Tr1-like T cells.

Keywords: Tr-1 T cells, IL-10, CD4 ${ }^{+} \mathrm{T}$ cell, inhibitory receptors, peripheral tolerance

\section{CD4+IL-10+ $T$ CELLS - A HETEROGENEOUS POPULATION OF CELLS WITH A SUPPRESSIVE FUNCTION}

In 1997, Groux et al. described a unique population of $\mathrm{CD}^{+} \mathrm{T}$ lymphocytes generated after in vitro stimulation of $\mathrm{CD}^{+}{ }^{+} \mathrm{T}$ cells from the T cell receptor (TCR) transgenic DO11-10 mouse with ovalbumin peptide (OVA) and IL-10 or with IL-10 alone. These OVA-specific $\mathrm{CD} 4^{+} \mathrm{T}$ cells produced high levels of IL-10 and IL-5, moderate levels of IFN $\gamma$ and TGF $\beta$, low levels of IL-2 and IL-4, and proliferated poorly in response to peptide stimulation (1). High levels of IL-10 suggested a regulatory potential for these cells, since IL-10 is crucial for limiting proinflammatory and autoimmune responses [reviewed in Ref. $(2,3)]$. IL-10-deficient mice develop severe colitis, accompanied by tissue damage and excessive inflammation (4). Analysis of this model as well as further studies demonstrated that IL-10 is able to block immune responses at different levels by acting directly and indirectly on both innate and adaptive arms of the immune system [reviewed in Ref. (5)]. As a result, IL-10 can inhibit production of proinflammatory cytokines, antigen presentation, and cell proliferation.

In the original paper, the reconstitution of SCID mice with naive $\mathrm{CD} 4^{+} \mathrm{T}$ cells and OVA-specific $\mathrm{CD} 4^{+} \mathrm{IL}-10^{+} \mathrm{T}$ cell clones resulted in prevention of colitis (1). Later on, several other groups confirmed 
the antigen-specific suppressive potential of CD4 $4^{+} \mathrm{IL}-10^{+} \mathrm{T}$ cells in vivo using colitis (4), experimental autoimmune encephalomyelitis (EAE) (6-10), collagen-induced arthritis (11), and allergy (12) disease models. Our laboratory has developed an animal model of multiple sclerosis (MS) using a TCR transgenic system. More than $90 \%$ of $\mathrm{CD}^{+}{ }^{+} \mathrm{T}$ cells in transgenic Tg4 mice express a VB8.2 TCR specific for the myelin basic protein (MBP) peptide Ac1-9 presented in the context of MHC I-A ${ }^{u}$ (13). This allowed us to conduct detailed phenotypic analysis of antigen-specific CD4 ${ }^{+} \mathrm{IL}-10^{+} \mathrm{T}$ cells and identify panel of inhibitory receptors (IRs), which could serve as markers for these cells (7), (see The Need to Discover a Surrogate Marker for Regulatory Tr1-Like T Cells).

CD4 ${ }^{+} \mathrm{IL}-10^{+} \mathrm{T}$ cells can also be generated using human peripheral blood mononuclear cells (PBMC) after stimulation with allogeneic monocytes in the presence of IL-10 (1). They produce high levels of IL-10 and low levels of IL-2 and IL-4, after re-stimulation with $\alpha \mathrm{CD} 3$ and $\alpha \mathrm{CD} 28$ antibodies, and similar to the murine $\mathrm{CD} 4^{+} \mathrm{IL}-10^{+} \mathrm{T}$ cells can suppress responder $\mathrm{CD} 4^{+}$ $\mathrm{T}$ cells in vitro (14-17). These results were obtained using several different protocols for the generation of the CD4 $4^{+} \mathrm{IL}-10^{+} \mathrm{T}$ cell population. They involved stimulation with a specific subset of antigen-presenting cells, including plasmacytoid dendritic cells (DCs), immature DCs, or tolerogenic DC (1, 18-20); the presence of cytokines, including IL-10, IL-6, IL-21, or IL-27 (21-24); or using antibodies against various costimulatory molecules, such as CD46, CD2, and $\operatorname{CD} 55(25,26)$, as well as vitamin D3 and immunosuppressive drugs (27). Different laboratories adopted a different set of stimuli, which in their experimental setup worked most efficiently to generate high numbers of $\mathrm{CD}^{+} \mathrm{IL}-10^{+} \mathrm{T}$ cells. However, one could question the physiological relevance of such manipulations, because they cannot re-create a complex in vivo environment. Also, different protocols result in the emergence of various subpopulations of $\mathrm{CD} 4^{+} \mathrm{IL}-10^{+} \mathrm{T}$ cells, making characterization of these cells and discovery of specific marker/s of the CD $4^{+} \mathrm{IL}-10^{+} \mathrm{T}$ cell population even more challenging. Despite the heterogeneity of the described human $\mathrm{CD} 4^{+} \mathrm{IL}-10^{+}$populations, these are generally referred to as $\mathrm{T}$ regulatory type 1 cells ( $\operatorname{Tr} 1)$. Nevertheless, it is worth noting that to date, it has not been proven that they represent a unique cell lineage; therefore, we will refer them here as Tr1-like T cells.

\section{THE NEED TO DISCOVER A SURROGATE MARKER FOR REGULATORY Tr1-LIKE T CELLS}

The existence of antigen-specific suppressor $\operatorname{Tr} 1$-like $\mathrm{T}$ cells makes them an appealing target for designing antigen-specific therapies to treat a wide array of autoimmune diseases and to avoid unnecessary and often burdensome side effects associated with conventional immunosuppressive therapies (28). A constitutively expressed surface marker for Tr1-like T cells would allow us to monitor the emergence, numbers, and functionality of these cells. Many groups have tried to identify such a marker in mouse and man $(16,29-32)$. In 2013, Gagliani et al. postulated that lymphocyte-activation protein 3 (LAG-3) and CD49b are markers for human Tr1-like T cells (17). LAG-3 belongs to a large family of IRs that are upregulated on activated T cells (33). Here, we discuss the significance of the published findings in the context of other relevant IRs.

The in vivo data from our laboratory (7) demonstrated that administration of soluble MBP Ac1-9 peptide, using a dose escalation protocol, resulted in abrogation of EAE, which coincided with appearance of antigen-specific $\mathrm{CD} 4^{+} \mathrm{IL}-10^{+} \mathrm{T}$ cells. A majority of these cells expressed $\mathrm{T}$ cell immunoglobulin and mucin domain-3 (TIM-3), T-cell immunoreceptor with Ig and ITIM domains (TIGIT), and $50 \%$ of the cells were CD $49 \mathrm{~b}^{+}$, which is in sharp contrast with the expression pattern observed on the IL-10$\mathrm{T}$ cell subset, where all three markers were present in $6-9 \%$ of the cells. Programed cell death protein 1 (PD-1) and LAG-3 were found in the majority of $\mathrm{CD}^{+} \mathrm{T}$ cells, regardless of IL-10 production. These IRs are involved in several mechanisms regulating T cell signaling [reviewed in Ref. $(33,34)$ ]. PD- 1 and TIM- 3 bind intracellular mediators as SHIP-1/2 (PD-1), Fyn, and PI3K kinase (TIM-3) to deactivate the downstream signaling molecules, and PD-1 can also induce inhibitory genes that inhibit $\mathrm{T}$ cell function. TIGIT and LAG-3 prevent optimal signal transduction at the cell membrane by sequestering counter receptors/ligands together with preventing proper formation of the immunological synapse [reviewed in Ref. $(33,34)]$. Importantly, these events are dysregulated not only during autoimmune responses (35-37) but also in tumor formation. PD-1, TIM-3, and LAG-3 are found in T cells isolated from melanoma patients (38-40); therefore, their expression on T cells is also relevant for the development of new anticancer therapies.

PD-1, belonging to the CD28/CTLA-4 family, provides a negative signal following antigen stimulation [reviewed in Ref. (41)]. Depending on the genetic background, $\mathrm{PD}-1^{-/-}$mice develop a range of autoimmune disorders: lupus-like glomerulonephritis in the C57BL/6 strain, autoimmune dilated cardiomyopathy and gastritis in BALB/C, acute type 1 diabetes mellitus (T1DM) in NOD (42), and myocarditis in MRL, suggesting that other genetic, inherent factors act synergistically with PD-1 in each mouse strain (36). Clearly, PD-1 plays an important role in the maintenance of peripheral tolerance, but due to abundant expression on activated $\mathrm{T}$ cells, it is unlikely to be a biomarker for Tr1-like T cells.

Apart from PD-1, deficiency in any other of the abovementioned IRs does not result in the spontaneous development of autoimmune disorders. NOD LAG-3-deficient mice show mild enhancement of $\mathrm{T}$ lymphocyte responses, unless crossed with PD-1 $1^{-1-}$ knockout mice, which causes a lethal myocarditis (36). TIGIT $^{-1-}$ mice are more susceptible to EAE and show only augmented $\mathrm{T}$ cell responses when challenged with MOG peptide in vivo (37). CD49b deficiency leads to failure of the establishment of memory $\mathrm{T}$ cells in the bone marrow (43), but it does not have any profound effect on peripheral tolerance, while TIM- $3^{-1-}$ mice and mice treated with a TIM-3 Ig fusion protein exhibit moderate defects in induction of antigen-specific tolerance [reviewed in Ref. (44)].

Regarding surface expression, most of the above-mentioned IRs are found in cells with regulatory properties. TIGIT is expressed on human Tr1-like T cells (our observation) but also 
A

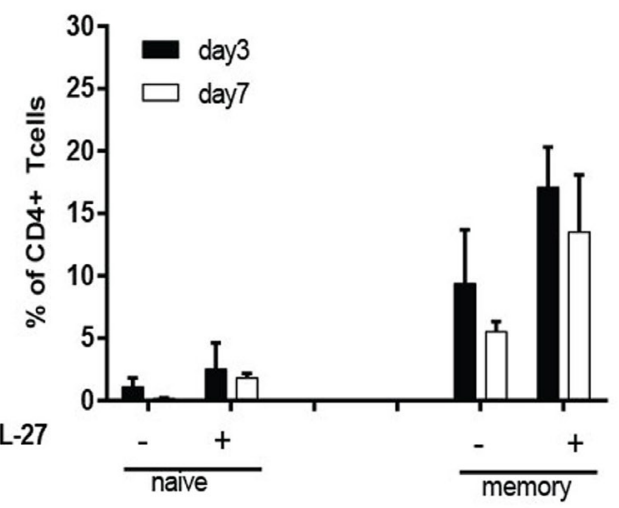

B
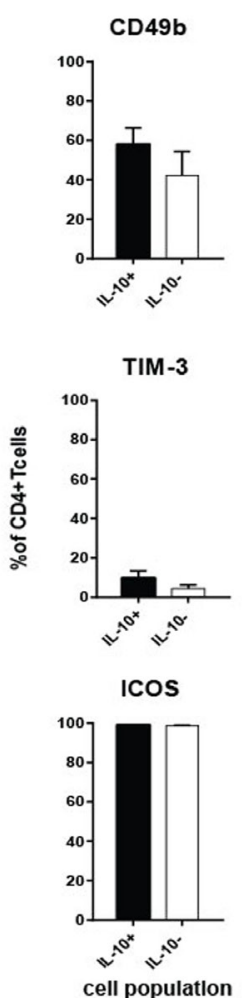

IL-10+
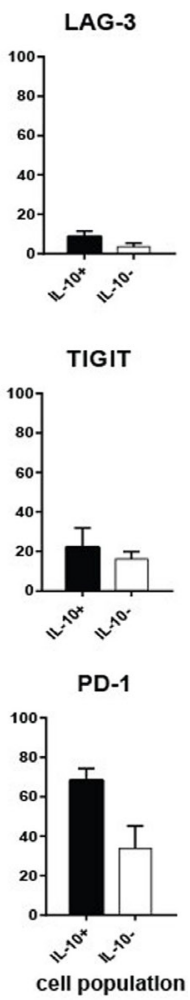

Day3
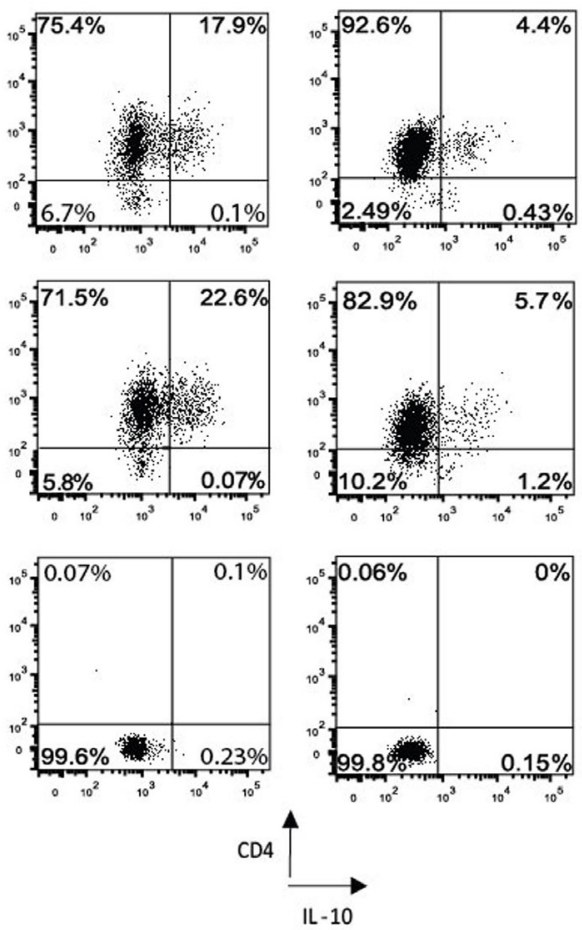

IL-10+
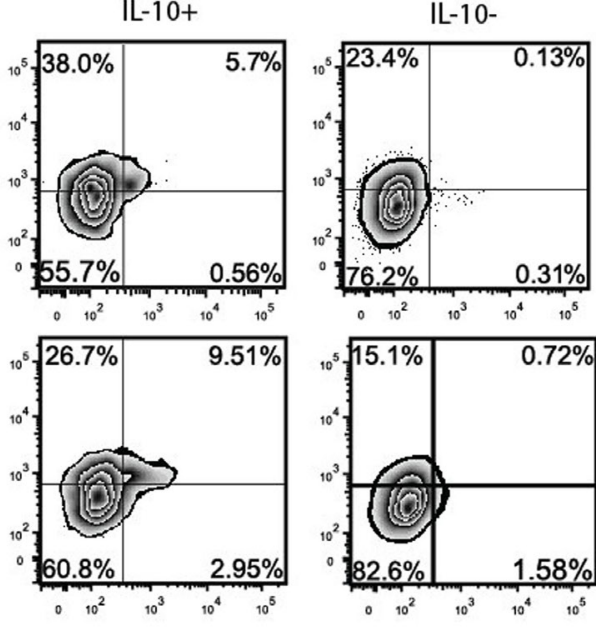

+ IL-27
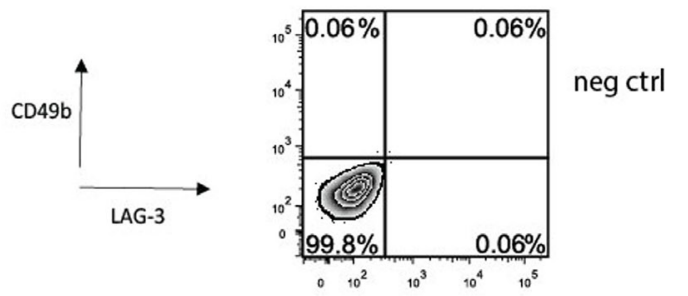

FIGURE 1 | Continued 


\section{FIGURE 1 | Continued}

(A) Naive and memory CD4 ${ }^{+} \mathrm{T}$ cells were isolated from PBMC from healthy donors by magnetic selection and stimulated with plate-bound $1 \mu \mathrm{g} / \mathrm{ml} \alpha \mathrm{CD} 3$ and $2 \mu \mathrm{g} / \mathrm{ml} \alpha \mathrm{CD} 28 \pm 100 \mathrm{ng} / \mathrm{ml}$ of IL-27. Intracellular staining for IL-10 was performed on days 3 and 7 after an additional 4-h stimulation with PMA/ionomycin in the presence of Golgi stop. Graphs show the percentages (mean value \pm SEM, $n=3$ donors) of viable CD4+IL-10+ $\mathrm{T}$ cells derived from the naive or memory cell subsets (left panel). A representative dot plot of CD4 and IL-10 staining on memory-derived CD4+ $\mathrm{T}$ cells on day 7 is shown in the right panel. (B) Expression of inhibitory receptors (IRs) on CD4+IL-10 ${ }^{+/-}$T cells derived from memory pool after 7 days of cell culture in the presence of $1 \mu \mathrm{g} / \mathrm{ml} \alpha \mathrm{CD} 3$ and $2 \mu \mathrm{g} / \mathrm{ml} \alpha \mathrm{CD} 28$ examined by flow cytometry. The black bars represent the average percentage of $\mathrm{IL}-10^{+}$and white bars the IL-10- cell fractions, respectively (mean $+\mathrm{SEM}, n=3$ donors). Right panel shows a representative dot plot of CD49b and LAG-3 expression on day 7 by memory CD4+IL-10+/- stimulated with $\alpha \mathrm{CD} 3$ and $\alpha \mathrm{CD} 28 \pm \mathrm{IL}-27$.

on human $\mathrm{T}_{\text {reg }}$ Foxp $3^{+}$cells (45). Furthermore, its presence at the cell surface coincides with increased expression of ICOS, TIM-3, and PD-1 on murine $\mathrm{T}_{\text {reg }}$ cells (37). TIM-3 is upregulated upon activation in vitro in the human $\mathrm{T}_{\text {reg }}$ subset (46). Recently, it has also been reported that murine $\mathrm{CD} 4{ }^{+} \mathrm{CD} 49 \mathrm{~b}^{+} \mathrm{T}$ cells produce high levels of IL-10 and are potent suppressors of arthritis severity when injected in vivo (47).

To gain a more detailed understanding of how the expression of PD-1, LAG-3, TIM-3, TIGIT, and ICOS correlates with IL-10 production by human $\mathrm{CD} 4^{+} \mathrm{T}$ cells, we developed a protocol to generate IL- $10^{+} \mathrm{CD} 4^{+} \mathrm{T}$ cells after a different length of stimulation in vitro. The first approach involved isolation of memory and naive $\mathrm{T}$ cells and stimulating them with $\alpha \mathrm{CD} 3$ and $\alpha \mathrm{CD} 28$ antibodies in presence or absence of IL-27, known stimuli for Tr1-like T cell generation $(21,22)$. IL-27 boosted the percentages of CD $4^{+} \mathrm{IL}-10^{+}$ $\mathrm{T}$ cells from 10 to $18 \%$ on day 3 , which on day 7 decreased to $14 \%$ in the presence of IL-27 and 5\% in its absence (Figure 1A). However, adding IL-27 did not alter the surface phenotype of Tr1-like T cells (data not shown). Initially, the induction of IL-10 production was accompanied by a slight increase in proportions of cells expressing CD49b and TIM-3 within the IL-10+ $\mathrm{T}$ cell subset, but this was not statistically significant. By day 7, CD49b was found in similar percentages on both IL- $10^{+}$and IL- $10^{-}$ T cells (Figure 1B). CD49b and TIM-3 were co-expressed by the IL- $10^{+} \mathrm{T}$ cell fraction, but on day $7, \mathrm{CD} 49 \mathrm{~b}^{+}$cells were mainly TIM-3- ${ }^{-}$LAG-3 was expressed by $8.6 \%$ of $\mathrm{IL}-10^{+} \mathrm{T}$ cells on day 7 (Figure 1B), and among these cells, 30\% co-expressed TIM-3. The co-expression of LAG-3 and CD49b was observed only on a small proportion of IL-10+ $10^{+}$subset (Figure 1B, right panel). The proportion of cells expressing TIGIT was similar between IL-10 ${ }^{+}$ and IL-10- $0^{-}$subsets of $\mathrm{CD}^{+} \mathrm{T}$ cells (Figure 1B), and approximately half of them co-expressed TIM-3. Our observations led us to conclude that none of the tested IRs are exclusively expressed on IL-10-producing T cells, and their expression is dynamic, changing over the time course of cell culture.

These results were very different from the data generated in vivo in the tolerance model (7). Therefore, we used a modified version of the protocol previously developed in our laboratory (48), which involved the ex vivo isolation of IL- $10^{+} \mathrm{CD} 4^{+} \mathrm{T}$ cells, a short stimulation of unfractionated $\mathrm{CD} 4^{+} \mathrm{T}$ cells with $\alpha \mathrm{CD} 3$ and $\alpha \mathrm{CD} 28$ antibodies, followed by IL-10 cytokine secretion assay to allow sorting of IL- $10^{+}$cells. This strategy minimized the manipulation of cells in vitro but still allowed us to obtain a sufficient number of CD4 $4^{+} \mathrm{IL}-10^{+} \mathrm{T}$ cells for analysis $\left(3-5 \%\right.$ of total CD $4^{+}$ $\mathrm{T}$ cells). The phenotype of highly purified IL- $10^{+}$cells differed significantly from the IL-10- subpopulation. TIM-3 expression was significantly higher on IL-10 $0^{+} \mathrm{T}$ cells as compared to the IL- $10^{-}$subset $(p=0.0008)$ and was present in approximately
$25 \%$ of $\mathrm{CD}^{+} \mathrm{T}$ cells, while $80 \%$ of $\mathrm{CD} 4^{+} \mathrm{IL}-10^{+} \mathrm{T}$ cells expressed PD-1 $(p=0.007)$, which was significantly higher when compared to the IL- $10^{-}$fraction. Within the $\mathrm{PD}-1^{+} \mathrm{T}$ cell population, the percentages of $\mathrm{CD}_{4} 9 \mathrm{~b}^{+}$and $\mathrm{LAG}-3^{+}$cells were lower, both below $10 \%$ and although higher than the IL- $10^{+}$subset, the differences were not statistically significant (Figure 2A).

To correlate the surface phenotype with RNA levels, we performed RT-PCR on restimulated IL- $10^{+}$and $\mathrm{IL}^{-10^{-}}$cells, which were previously rested for $48 \mathrm{~h}$ in the presence of human recombinant IL-2. RT-PCR analysis demonstrated a significant increase in TIGIT expression among IL-10 $0^{+} \mathrm{T}$ cells $(p=0.03)$ and a trend toward higher levels of TIM-3 mRNA levels among IL-10+ T cells as compared to the IL-10- T cell subset (Figure 2B), pointing to these two markers as preferential for $\operatorname{Tr} 1$-like T cells. However, our flow cytometry analysis of surface IR levels performed at the same time point resulted in a different pattern of expression. There were no statistically significant differences in TIM-3 expression between IL- $10^{+}$and IL-10- $\mathrm{T}$ cells (approximately 10\%), similar to LAG- $3^{+}(5 \%)$, much lower as compared to relative RNA levels. By contrast, $\mathrm{TIGIT}^{+} \mathrm{IL}-10^{+} \mathrm{T}$ cells comprised $25 \%$ and $\mathrm{PD}-1^{+} 50 \%$ of IL- $10^{+} \mathrm{T}$ cells, while their RNA levels were lower than those of TIM-3 and LAG-3. It is also important to note that there were no noticeable differences in the percentages of TIM-3, TIGIT, and PD- 1 between IL- $10^{+}$and IL- $10^{-}$T cell subsets at this time point (Figure 2C). This result could be explained by the fact that these IRs are stored intracellularly (49-51) and released to the surface with different kinetics; so although their mRNA is upregulated, this may contribute to intracellular pools rather than cell surface expression of the markers. It has been previously shown that large pools of LAG-3 are stored intracellularly (49), and we were able to detect large proportions of intracellular LAG-3 in both IL-10+ and IL-10- T cells (data not shown). It is possible that the kinetics of LAG-3 release to the cell surface correlates with the suppressive phenotype of the cells. In the same way, surface expression of TIM-3, known to reside in the Golgi apparatus and endoplasmic reticulum (50), could be differentially regulated on the IL- $10^{+}$ as compared to the $\mathrm{CD} 4^{+} \mathrm{IL}-10^{-}$subpopulation. There is also evidence for altered regulation of TIM-3 expression in acute myeloid leukemia, where the majority of TIM-3 is expressed on the surface of PMBC as compared to healthy individuals, where TIM-3 is mainly detected intracellularly (51).

\section{BEYOND IRs}

Due to the lack of any firm evidence demonstrating an exclusive IR marker for Tr1-like $\mathrm{T}$ cells, emerging evidence points toward new molecules that might serve as their biomarkers. In 2015, Blumberg's group published a very elegant study in 


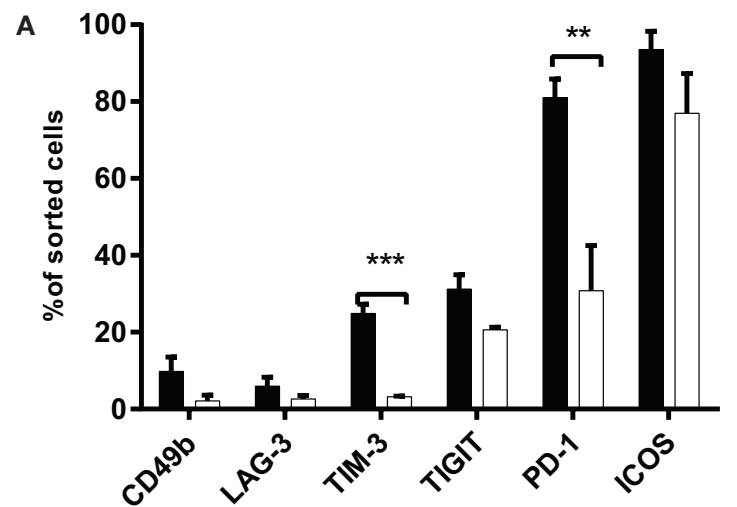

B
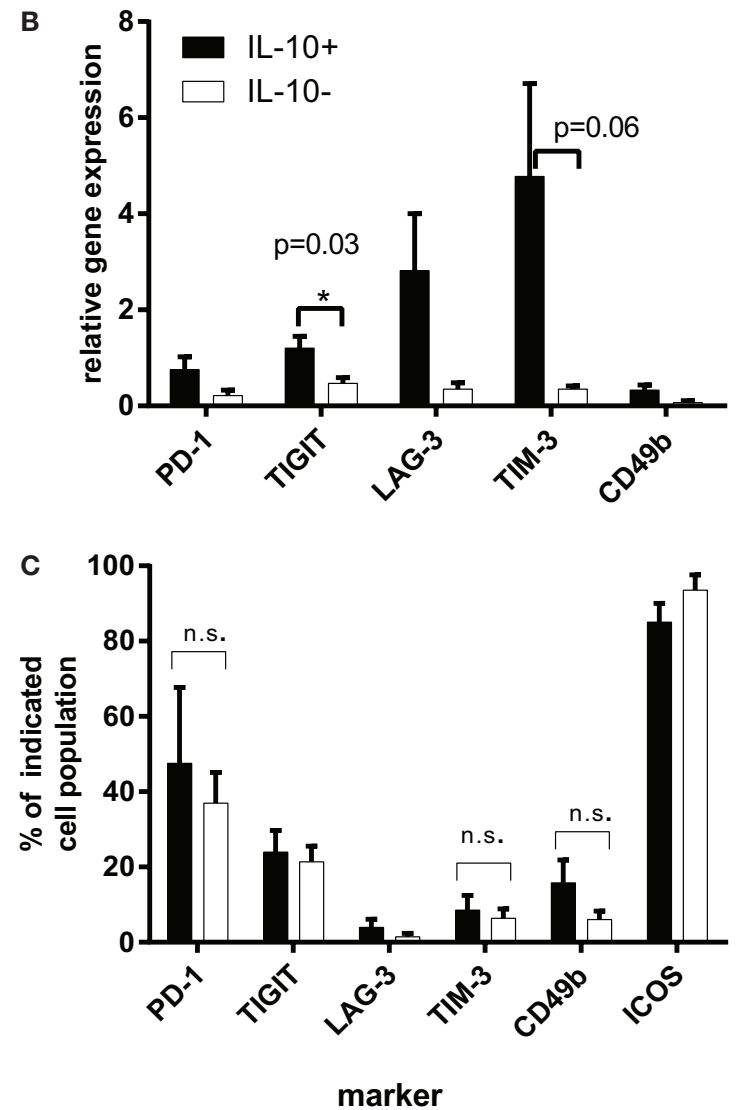

FIGURE 2 | (A) The expression of IRs on purified CD4+|L-10+/L-10$T$ cells. Magnetically sorted CD4+ $T$ cells were cultured for $16 \mathrm{~h}$ in the presence of $1 \mu \mathrm{g} / \mathrm{ml} \alpha \mathrm{CD} 3$ and $2 \mu \mathrm{g} / \mathrm{ml}$ of $\alpha \mathrm{CD} 28$ antibodies, then harvested, subjected to IL-10 cytokine secretion assay, and sorted by flow cytometry according to their IL-10 expression. Graphs represent the percentages of $\mathrm{IL}-10^{+}$or $\mathrm{LL}-10^{-} \mathrm{T}$ cells, expressing each IR determined by flow cytometry $(n=4)$. Purified CD4+IL-10+/- T cells were rested for $48 \mathrm{~h}$ in the presence of $60 \mathrm{U} / \mathrm{ml} \mathrm{IL}-2$ and then were restimulated for $4 \mathrm{~h}$ with $\alpha \mathrm{CD} 3$ and $\alpha \mathrm{CD} 28$ antibodies. (B) mRNA levels of IRs on sorted CD4+IL-10 $\mathrm{O}^{+/-} \mathrm{T}$ cells. Purified $\mathrm{CD} 4^{+} \mathrm{IL}-10^{+/-} \mathrm{T}$ cells were rested for $48 \mathrm{~h}$ in the presence of $60 \mathrm{U} / \mathrm{ml} \mathrm{IL}-2$ and then were restimulated for $4 \mathrm{~h}$ with $\alpha \mathrm{CD} 3$ and $\alpha \mathrm{CD} 28$ antibodies. Graphs show mean gene expression levels as relative values compared to HPRT-1 $(n=4)$. (C) Expression of IRs on CD4+IL-10+/- T cell fraction at the point of RNA isolation as evaluated by flow cytometry. Figure shows percentages of viable CD4+IL-10 $0^{+/-} \mathrm{T}$ cells expressing the indicated marker (mean + SEM, $n=4)$. The significance has been analyzed using $t$ test. which they demonstrated that surface expression of TIM-3 is regulated by carcinoembryonic antigen cell adhesion molecule 1 (CEACAM-1), which has the ability to form a heterodimer with TIM-3 in human and murine $\mathrm{CD} 4^{+} \mathrm{T}$ cells (50). Furthermore, lower proportions of tumor-infiltrating murine $\mathrm{CD} 4^{+}$and $\mathrm{CD} 8^{+}$ $\mathrm{T}$ cells produced IL-10 after co-blockade of CEACAM-1 and TIM-3 in vivo (50). Equally, one could speculate that CEACAM-1 could also regulate surface expression of TIM-3 on Tr1-like T cells; however, the CEACAM-1 expression on Tr1-like T cells has not yet been studied. It is known that this molecule is expressed on a small population of resting $\mathrm{CD} 4^{+} \mathrm{T}$ cells in humans and mice (52); hence, it could be a potential candidate for a biomarker for Tr1-like T cells.

The second putative candidate is Granzyme B. Previous studies have shown that human and murine $\mathrm{CD} 4^{+} \mathrm{T}$ cells, which acquire a Tr-1-like phenotype, express Granzyme B (53-55). A recent publication by Schmetterer et al. demonstrates that human $\mathrm{CD}^{+} \mathrm{T}$ cells transduced with the active form of STAT3 produce higher levels of IL-10 and Granzyme B, which was responsible for the suppressive activity of these cells (56). It is worthwhile to point out that the cells did not display elevated levels of CD49b and LAG-3 (56). Interestingly, blocking CEACAM1 increased the cytolytic function of human CD8 $8^{+} \mathrm{T}$ cells (52); hence, this molecule if expressed on CD4 ${ }^{+} \mathrm{IL}-10^{+} \mathrm{T}$ cells could influence their cytotoxic function by regulating Granzyme B expression.

The third possible candidate to serve as a marker for $\operatorname{Tr} 1$-like $\mathrm{T}$ cells is class I-restricted T cell-associated molecule (CRTAM) expressed on both $\mathrm{CD}^{+}$and $\mathrm{CD} 8^{+} \mathrm{T}$ cells upon activation. This molecule was upregulated on Tr1-like T cells as a result of tolerance induction after administration of escalating doses of MBP peptide (7). Recently, Saito's group demonstrated that CRTAM is expressed on a specific subset of $\mathrm{CD} 4^{+} \mathrm{T}$ cells, which are characterized by high production of IFN $\gamma$, expression of Granzyme B, and Eomes after TCR activation, and can develop cytotoxic properties in both mice and humans (57). A comparison of the phenotype of $\mathrm{CD}^{+}{ }^{+} \mathrm{CRTAM}^{+} \mathrm{T}$ cells with Tr1-like $\mathrm{T}$ cells in relation to expression of Granzyme B and CEACAM-1 would provide an insight into the functional differences within a heterogeneous subset of human Tr1-like T cells, especially given that, according to our observations, $50 \%$ of these cells expressed IFN $\gamma$.

In summary, our phenotypic analyses suggest that none of the analyzed IRs can be described as surrogate markers for Tr1-like $\mathrm{T}$ cells. Ideally, such a biomarker would be a stable, constitutively expressed cell surface molecule, easily detected on freshly isolated human $\mathrm{CD} 4^{+} \mathrm{T}$ cells. In the quest to identify it, more detailed analyses using RNA profiling and unbiased proteomics together with studies of epigenetic changes at the IL-10 promoter should be performed. Our laboratory analyzed changes in histone $\mathrm{H} 3$ modification at the IL-10 promoter and found similar epigenetic changes in mouse and human CD4 $4^{+} \mathrm{IL}-10^{+} \mathrm{T}$ cells (58). However, Dong et al. found limited epigenetic changes in the status of human IL-10 promoter and a lack of functional memory for IL-10 re-expression in cultured IL-10 secreting cells (59). It is clear that all T cell subsets can secrete IL-10 under certain circumstances (3). Therefore, the question as to whether $\operatorname{Tr} 1$ cells constitute a distinct lineage remains open and requires further investigation. 


\section{ETHICS STATEMENT}

NRES Committee North West - Greater Manchester West, Ethical Permission 14/NW/0152. The study did not require consent because it was anonymized study, and we used lymphocyte cones purchased from the NHS blood bank in Bristol, United Kingdom.

\section{AUTHOR CONTRIBUTIONS}

AW performed experimental work and wrote the manuscript. DW coordinated the experimental work and co-wrote the manuscript.

\section{REFERENCES}

1. Groux H, O'Garra A, Bigler M, Rouleau M, Antonenko S, De Vries JE, et al. A CD4+ T-cell subset inhibits antigen-specific T-cell responses and prevents colitis. Nature (1997) 389:737-42. doi:10.1038/39614

2. Moore KW, De Waal Malefyt R, Coffman RL, O'Garra A. Interleukin-10 and the interleukin-10 receptor. Annu Rev Immunol (2001) 19:683-765. doi:10.1146/annurev.immunol.19.1.683

3. Ng TH, Britton GJ, Hill EV, Verhagen J, Burton BR, Wraith DC. Regulation of adaptive immunity; the role of interleukin-10. Front Immunol (2013) 4:129. doi:10.3389/fimmu.2013.00129

4. Kuhn R, Lohler J, Rennick D, Rajewsky K, Muller W. Interleukin-10deficient mice develop chronic enterocolitis. Cell (1993) 75:263-74. doi:10.1016/0092-8674(93)80068-P

5. Saxena A, Khosraviani S, Noel S, Mohan D, Donner T, Hamad AR. Interleukin-10 paradox: a potent immunoregulatory cytokine that has been difficult to harness for immunotherapy. Cytokine (2015) 74:27-34. doi:10.1016/j.cyto.2014.10.031

6. Gabrysova L, Wraith DC. Antigenic strength controls the generation of antigen-specific IL-10-secreting T regulatory cells. Eur J Immunol (2010) 40:1386-95. doi:10.1002/eji.200940151

7. Burton BR, Britton GJ, Fang H, Verhagen J, Smithers B, Sabatos-Peyton $\mathrm{CA}$, et al. Sequential transcriptional changes dictate safe and effective antigen-specific immunotherapy. Nat Commun (2014) 5:4741. doi:10.1038/ ncomms5741

8. Nicolson KS, O’Neill EJ, Sundstedt A, Streeter HB, Minaee S, Wraith DC. Antigen-induced IL-10+ regulatory T cells are independent of CD25+ regulatory cells for their growth, differentiation, and function. J Immunol (2006) 176:5329-37. doi:10.4049/jimmunol.176.9.5329

9. Verhagen J, Gabrysova L, Shepard ER, Wraith DC. Ctla-4 modulates the differentiation of inducible Foxp3+ Treg cells but IL-10 mediates their function in experimental autoimmune encephalomyelitis. PLoS One (2014) 9:e108023. doi:10.1371/journal.pone.0108023

10. Bettelli E, Das MP, Howard ED, Weiner HL, Sobel RA, Kuchroo VK. IL-10 is critical in the regulation of autoimmune encephalomyelitis as demonstrated by studies of IL-10- and IL-4-deficient and transgenic mice. J Immunol (1998) 161:3299-306.

11. Johansson AC, Hansson AS, Nandakumar KS, Backlund J, Holmdahl R. IL-10-deficient B10.Q mice develop more severe collagen-induced arthritis, but are protected from arthritis induced with anti-type II collagen antibodies. J Immunol (2001) 167:3505-12. doi:10.4049/jimmunol.167.6.3505

12. Akdis CA, Blaser K. IL-10-induced anergy in peripheral T cell and reactivation by microenvironmental cytokines: two key steps in specific immunotherapy. FASEB J (1999) 13:603-9.

13. Liu GY, Fairchild PJ, Smith RM, Prowle JR, Kioussis D, Wraith DC. Low avidity recognition of self-antigen by $\mathrm{T}$ cells permits escape from central tolerance. Immunity (1995) 3:407-15. doi:10.1016/1074-7613(95)90170-1

14. Levings MK, Roncarolo MG. T-regulatory 1 cells: a novel subset of CD4 $\mathrm{T}$ cells with immunoregulatory properties. J Allergy Clin Immunol (2000) 106:S109-12. doi:10.1067/mai.2000.106635

15. Vieira PL, Christensen JR, Minaee S, O’Neill EJ, Barrat FJ, Boonstra A, et al. IL-10-secreting regulatory $\mathrm{T}$ cells do not express Foxp3 but have

\section{ACKNOWLEDGMENTS}

We would like to thank Dr. Bronwen Burton for the help with the experiments and for critical reading of the manuscript, and Dr. T. H. Sky Ng for technical help with RT-PCR. We would also like to acknowledge Dr. Andrew Herman for assistance with cell sorting. AW was awarded Daphne Jackson Fellowship.

\section{FUNDING}

This project has been funded by the Department of Cellular and Molecular Medicine, University of Bristol, United Kingdom in the frame of Daphne Jackson Fellowship scheme.

comparable regulatory function to naturally occurring CD4+CD25+ regulatory T cells. J Immunol (2004) 172:5986-93. doi:10.4049/jimmunol.172. 10.5986

16. Haringer B, Lozza L, Steckel B, Geginat J. Identification and characterization of IL-10/IFN-gamma-producing effector-like T cells with regulatory function in human blood. J Exp Med (2009) 206:1009-17. doi:10.1084/jem.20082238

17. Gagliani N, Magnani CF, Huber S, Gianolini ME, Pala M, Licona-Limon $\mathrm{P}$, et al. Coexpression of CD49b and LAG-3 identifies human and mouse T regulatory type 1 cells. Nat Med (2013) 19:739-46. doi:10.1038/nm.3179

18. Pletinckx K, Vaeth M, Schneider T, Beyersdorf N, Hunig T, Berberich-Siebelt $\mathrm{F}$, et al. Immature dendritic cells convert anergic nonregulatory $\mathrm{T}$ cells into Foxp3- IL-10+ regulatory T cells by engaging CD28 and CTLA-4. Eur J Immunol (2015) 45:480-91. doi:10.1002/eji.201444991

19. Jonuleit H, Schmitt E, Schuler G, Knop J, Enk AH. Induction of interleukin 10-producing, nonproliferating $\mathrm{CD} 4(+) \mathrm{T}$ cells with regulatory properties by repetitive stimulation with allogeneic immature human dendritic cells. J Exp Med (2000) 192:1213-22. doi:10.1084/jem.192.9.1213

20. Amodio G, Gregori S. Human tolerogenic DC-10: perspectives for clinical applications. Transplant Res (2012) 1:14. doi:10.1186/2047-1440-1-14

21. Murugaiyan G, Mittal A, Lopez-Diego R, Maier LM, Anderson DE, Weiner HL. IL-27 is a key regulator of IL-10 and IL-17 production by human CD4+ T cells. J Immunol (2009) 183:2435-43. doi:10.4049/ jimmunol.0900568

22. Pot C, Jin H, Awasthi A, Liu SM, Lai CY, Madan R, et al. Cutting edge: IL-27 induces the transcription factor c-Maf, cytokine IL-21, and the costimulatory receptor ICOS that coordinately act together to promote differentiation of IL-10-producing Tr1 cells. J Immunol (2009) 183:797-801. doi:10.4049/ jimmunol.0901233

23. Wang H, Meng R, Li Z, Yang B, Liu Y, Huang F, et al. IL-27 induces the differentiation of Tr1-like cells from human naive CD4+ T cells via the phosphorylation of STAT1 and STAT3. Immunol Lett (2011) 136:21-8. doi:10.1016/j. imlet.2010.11.007

24. Jin JO, Han X, Yu Q. Interleukin-6 induces the generation of IL-10-producing $\operatorname{Tr} 1$ cells and suppresses autoimmune tissue inflammation. JAutoimmun (2013) 40:28-44. doi:10.1016/j.jaut.2012.07.009

25. Kemper C, Chan AC, Green JM, Brett KA, Murphy KM, Atkinson JP. Activation of human CD4+ cells with CD3 and CD46 induces a T-regulatory cell 1 phenotype. Nature (2003) 421:388-92. doi:10.1038/nature01315

26. Sutavani RV, Bradley RG, Ramage JM, Jackson AM, Durrant LG, Spendlove I. CD55 costimulation induces differentiation of a discrete T regulatory type 1 cell population with a stable phenotype. J Immunol (2013) 191:5895-903. doi:10.4049/jimmunol.1301458

27. Barrat FJ, Cua DJ, Boonstra A, Richards DF, Crain C, Savelkoul HF, et al. In vitro generation of interleukin 10-producing regulatory CD4(+) $\mathrm{T}$ cells is induced by immunosuppressive drugs and inhibited by T helper type 1 (Th1)and Th2-inducing cytokines. JExp Med (2002) 195:603-16. doi:10.1084/ jem.20011629

28. Saidha S, Eckstein C, Calabresi PA. New and emerging disease modifying therapies for multiple sclerosis. Ann N Y Acad Sci (2012) 1247:117-37. doi:10.1111/j.1749-6632.2011.06272.x

29. Bacchetta R, Sartirana C, Levings MK, Bordignon C, Narula S, Roncarolo MG. Growth and expansion of human T regulatory type 1 cells are independent from 
TCR activation but require exogenous cytokines. Eur J Immunol (2002) 32: 2237-45. doi:10.1002/1521-4141(200208)32:8<2237::AID-IMMU2237>3.0. $\mathrm{CO} ; 2-2$

30. Cobbold SP, Nolan KF, Graca L, Castejon R, Le Moine A, Frewin M, et al. Regulatory $\mathrm{T}$ cells and dendritic cells in transplantation tolerance: molecular markers and mechanisms. Immunol Rev (2003) 196:109-24. doi:10.1046/j.1600-065X.2003.00078.x

31. Rahmoun M, Foussat A, Groux H, Pene J, Yssel H, Chanez P. Enhanced frequency of CD18- and CD49b-expressing T cells in peripheral blood of asthmatic patients correlates with disease severity. Int Arch Allergy Immunol (2006) 140:139-49. doi:10.1159/000092533

32. Schuler PJ, Saze Z, Hong CS, Muller L, Gillespie DG, Cheng D, et al. Human CD4+ CD39+ regulatory $\mathrm{T}$ cells produce adenosine upon co-expression of surface CD73 or contact with CD73+ exosomes or CD73+ cells. Clin Exp Immunol (2014) 177:531-43. doi:10.1111/cei.12354

33. Chen L, Flies DB. Molecular mechanisms of T cell co-stimulation and co-inhibition. Nat Rev Immunol (2013) 13:227-42. doi:10.1038/nri3405

34. Thaventhiran T. T cell co-inhibitory receptors-functions and signalling mechanisms. J Clin Cell Immunol (2013) 1. doi:10.4172/2155-9899.S12-005

35. Wang J, Okazaki IM, Yoshida T, Chikuma S, Kato Y, Nakaki F, et al. PD-1 deficiency results in the development of fatal myocarditis in MRL mice. Int Immunol (2010) 22:443-52. doi:10.1093/intimm/dxq026

36. Okazaki T, Okazaki IM, Wang J, Sugiura D, Nakaki F, Yoshida T, et al. PD-1 and LAG-3 inhibitory co-receptors act synergistically to prevent autoimmunity in mice. J Exp Med (2011) 208:395-407. doi:10.1084/jem.20100466

37. Joller N, Hafler JP, Brynedal B, Kassam N, Spoerl S, Levin SD, et al. Cutting edge: TIGIT has T cell-intrinsic inhibitory functions. JImmunol (2011) 186:1338-42. doi:10.4049/jimmunol.1003081

38. Fourcade J, Sun Z, Benallaoua M, Guillaume P, Luescher IF, Sander C, et al. Upregulation of Tim-3 and PD-1 expression is associated with tumor antigen-specific CD8+ T cell dysfunction in melanoma patients. J Exp Med (2010) 207:2175-86. doi:10.1084/jem.20100637

39. Anderson AC. Tim-3: an emerging target in the cancer immunotherapy landscape. Cancer Immunol Res (2014) 2:393-8. doi:10.1158/2326-6066. CIR-14-0039

40. Gros A, Robbins PF, Yao X, Li YF, Turcotte S, Tran E, et al. PD-1 identifies the patient-specific CD8(+) tumor-reactive repertoire infiltrating human tumors. J Clin Invest (2014) 124:2246-59. doi:10.1172/JCI73639

41. FranciscoLM,SagePT,SharpeAH.ThePD-1 pathwayintoleranceandautoimmunity. Immunol Rev (2010) 236:219-42. doi:10.1111/j.1600-065X.2010.00923.x

42. Wang J, Yoshida T, Nakaki F, Hiai H, Okazaki T, Honjo T. Establishment of NOD-Pdcd1-/- mice as an efficient animal model of type I diabetes. Proc Natl Acad Sci U S A (2005) 102:11823-8. doi:10.1073/pnas.0505497102

43. Hanazawa A, Hayashizaki K, Shinoda K, Yagita H, Okumura K, Lohning M, et al. CD49b-dependent establishment of T helper cell memory. Immunol Cell Biol (2013) 91:524-31. doi:10.1038/icb.2013.36

44. Sakuishi K, Jayaraman P, Behar SM, Anderson AC, Kuchroo VK. Emerging Tim-3 functions in antimicrobial and tumor immunity. Trends Immunol (2011) 32:345-9. doi:10.1016/j.it.2011.05.003

45. Joller N, Lozano E, Burkett PR, Patel B, Xiao S, Zhu C, et al. Treg cells expressing the coinhibitory molecule TIGIT selectively inhibit proinflammatory Th1 and Th17 cell responses. Immunity (2014) 40:569-81. doi:10.1016/j. immuni.2014.02.012

46. Gautron AS, Dominguez-Villar M, De Marcken M, Hafler DA. Enhanced suppressor function of TIM-3+ FoxP3+ regulatory T cells. Eur J Immunol (2014) 44:2703-11. doi:10.1002/eji.201344392

47. Vicente R, Quentin J, Mausset-Bonnefont AL, Chuchana P, Martire D, Cren $\mathrm{M}$, et al. Nonclassical CD4+CD49b+ regulatory $\mathrm{T}$ cells as a better alternative to conventional CD4+CD25+ T cells to dampen arthritis severity. J Immunol (2016) 196:298-309. doi:10.4049/jimmunol.1501069

48. Mazza G, Sabatos-Peyton CA, Protheroe RE, Herman A, Campbell JD, Wraith DC. Isolation and characterization of human interleukin-10-secreting T cells from peripheral blood. Hum Immunol (2010) 71:225-34. doi:10.1016/ j.humimm.2009.12.003

49. Bae J, Lee SJ, Park CG, Lee YS, Chun T. Trafficking of LAG-3 to the surface on activated $\mathrm{T}$ cells via its cytoplasmic domain and protein kinase $\mathrm{C}$ signaling. J Immunol (2014) 193:3101-12. doi:10.4049/jimmunol.1401025

50. Huang YH, Zhu C, Kondo Y, Anderson AC, Gandhi A, Russell A, et al. CEACAM1 regulates TIM-3-mediated tolerance and exhaustion. Nature (2015) 517:386-90. doi:10.1038/nature13848

51. Goncalves Silva I, Gibbs BF, Bardelli M, Varani L, Sumbayev VV. Differential expression and biochemical activity of the immune receptor Tim-3 in healthy and malignant human myeloid cells. Oncotarget (2015) 6:33823-33. doi:10.18632/oncotarget.5257

52. Nagaishi T, Chen Z, Chen L, Iijima H, Nakajima A, Blumberg RS. CEACAM1 and the regulation of mucosal inflammation. Mucosal Immunol (2008) 1(Suppl 1):S39-42. doi:10.1038/mi.2008.50

53. Grossman WJ, Verbsky JW, Tollefsen BL, Kemper C, Atkinson JP, Ley TJ. Differential expression of granzymes A and B in human cytotoxic lymphocyte subsets and T regulatory cells. Blood (2004) 104:2840-8. doi:10.1182/ blood-2004-03-0859

54. Anderson PO, Manzo BA, Sundstedt A, Minaee S, Symonds A, Khalid S, et al. Persistent antigenic stimulation alters the transcription program in $\mathrm{T}$ cells, resulting in antigen-specific tolerance. Eur J Immunol (2006) 36:1374-85. doi:10.1002/eji.200635883

55. Gandhi R, Kumar D, Burns EJ, Nadeau M, Dake B, Laroni A, et al. Activation of the aryl hydrocarbon receptor induces human type 1 regulatory $\mathrm{T}$ cell-like and Foxp3(+) regulatory T cells. Nat Immunol (2010) 11:846-53. doi:10.1038/ ni. 1915

56. Schmetterer KG, Neunkirchner A, Wojta-Stremayr D, Leitner J, Steinberger P, Pickl WF. STAT3 governs hyporesponsiveness and granzyme B-dependent suppressive capacity in human CD4+ T cells. FASEB J (2015) 29:759-71. doi:10.1096/fj.14-257584

57. Takeuchi A, Badr Mel S, Miyauchi K, Ishihara C, Onishi R, Guo Z, et al. CRTAM determines the CD4+ cytotoxic T lymphocyte lineage. J Exp Med (2016) 213:123-38. doi:10.1084/jem.20150519

58. Hill EV, Ng TH, Burton BR, Oakley CM, Malik K, Wraith DC. Glycogen synthase kinase-3 controls IL-10 expression in CD4(+) effector T-cell subsets through epigenetic modification of the IL-10 promoter. Eur J Immunol (2015) 45:1103-15. doi:10.1002/eji.201444661

59. Dong J, Ivascu C, Chang HD, Wu P, Angeli R, Maggi L, et al. IL-10 is excluded from the functional cytokine memory of human CD4+ memory T lymphocytes. J Immunol (2007) 179:2389-96. doi:10.4049/ jimmunol.179.4.2389

Conflict of Interest Statement: The authors declare that the research was conducted in the absence of any commercial or financial relationships that could be construed as a potential conflict of interest.

Copyright (C) 2016 White and Wraith. This is an open-access article distributed under the terms of the Creative Commons Attribution License (CC BY). The use, distribution or reproduction in other forums is permitted, provided the original author $(s)$ or licensor are credited and that the original publication in this journal is cited, in accordance with accepted academic practice. No use, distribution or reproduction is permitted which does not comply with these terms. 